Nugroho, et al/Jurnal Ekonomi Syariah Teori dan Terapan Vol. 6 No. 11 November 2019: 2224-2235;

DETERMINAN PRICE EARNING RATIO SAHAM YANG TERDAFTAR DALAM JAKARTA ISLAMIC INDEX (JII) PERIODE $2011-2017$

\title{
DETERMINAN PRICE EARNING RATIO SAHAM YANG TERDAFTAR DALAM JAKARTA ISLAMIC INDEX (JII) PERIODE 2011 - 20171
}

\author{
Aysha Dhamaring Nugroho \\ Departemen Ekonomi Syariah-Fakultas Ekonomi dan Bisnis-Universitas Airlangga \\ Email: aysha.dhamaring.nugroho-2015@feb.unair.ac.id \\ Imron Mawardi \\ Departemen Ekonomi Syariah-Fakultas Ekonomi dan Bisnis-Universitas Airlangga \\ Email: ronmawardi@feb.unair.ac.id
}

\begin{abstract}
:
It is very important for investor to be able to assess whether a stock will be able to provide a high return of investment in the future. There are various kinds of approaches that can be used by investor to assess the performance of a stock in the stock market, two of which are technical analysis and fundamental analysis. Price earning ratio is part of ratio that are used in fundamental analysis and price earning ration is often used by investor as a refrence to read the performance of a stock in the future. This study are focusing on finding which variabel can affect the value of price earning ratio of a stock, using VECM method this study finds that debt to equity ratio, return on equity, dividend payout ratio and current ratio in long -run affecting price earning ratio in a significant way.
\end{abstract}

Keywords : financial ratio, price earning ratio, fundamental analysis, Indonesia syariah stock market

\section{PENDAHULUAN}

Sebelum melakukan investasi saham, ada baiknya calon investor melakukan pendekatan untuk memilih emiten mana yang sekiranya akan memberikan keuntungan hasil investasi yang tinggi. Terdapat dua metode pendekatan yang sering di gunakan oleh investor, metode tersebut adalah metode analisis teknikal dan metode analisis fundamental.

Metode analisis fundamental telah mendapatkan banyak perhatian dari para analisis sekuritas. Analisis fundamental didasari oleh pemahaman bahwa kondisi perusahaan tidak hanya dipengaruhi oleh faktor internal perusahaan tetapi juga faktor eksternal seperti kondisi ekonomi, pasar dan industri.

Dalam melakukan sebuah analisis fundamental analis dan investor harus memahami variable - variable yang mempengaruhi nilai intrinsik dari sebuah saham. Terdapat dua metode yang dapat digunakan dalam menaksir nilai intrinsik dari suatu saham, metode tersebut adalah Dividend Discount Model dan Price Earning Ratio. Metode yang paling sering digunakan oleh analis saham dan investor dalam melakukan penilaian saham adalah price earning ratio. Price earning ratio mempermuda para analis dan investor

\footnotetext{
${ }^{1}$ Jurnal ini adalah bagian dari skrispi Aysha Dhamaring Nugroho, NIM: 04151 1433193, yang diuji pada tanggal 21 Oktober 2019.
} 
Nugroho, et al/Jurnal Ekonomi Syariah Teori dan Terapan Vol. 6 No. 11 November 2019: 2224-2235; DETERMINAN PRICE EARNING RATIO SAHAM YANG TERDAFTAR DALAM JAKARTA ISLAMIC INDEX (JII) PERIODE $2011-2017$

dalam melakukan penilaian saham, seorang investor hanya perlu membagi harga perlembar saham dengan pendapatan perlembar saham untuk mengetahui price earning ratio dari saham tersebut.

\section{Tujuan}

Adapun tujuan dari penelitian ini adalah untuk meneliti rasio - rasio mana saja yang berpengaruh terhadap perubahan price earning ratio dari sebuah saham

\section{II. \\ LANDASAN TEORI PENGEMBANGAN HIPOTESIS}

DAN

\section{Analisis Fundamental}

Analisi saham dengan menggunakan pendekatan fundamental mencoba memperkirakan harga saham pada masa yang akan datang dengan melakukan estimasi pada nilai faktor faktor fundamental yang mempengaruhi laba saham pada masa yang akan datang. Halim (2015) dalam analisis ini dinyatakan bahwa saham memiliki nilai intrisik tertentu (nilai yang seharusnya). Analisis fundamental membandingnkan nilai intrinsic suatu saham dengan harga pasar dari saham dengan tujuan menentukan apakah harga pasar saham telah mencerminkan nilai intrinsiknya.

$$
\text { Analisis fundamental juga }
$$

menerapkan hubungan dari faktor - faktor tersebut sehingga diperoleh harga taksiran dari suatu saham. Metode yang digunakan dalam penilaian saham dengan menggunakan analisis fundamental meliputi pendekatan laba (price earning ratio approach) dan pendekatan nilai sekarang (present value approach).

\section{Price Earning Ratio}

Tandelilin (2010) Price Earning Ratio menggambarkan rasio atau perbandingan antara harga saham terhadap earning perusahaan. Fahmi (2014) menjelaskan bahwa Price Earning Ratio (rasio harga terhadap laba) merupakan perbandingan antara market price persahre (harga pasar perlembar saham dengan earning pershare (laba perlembar saham).

\section{Debt to Equity Ratio}

Debt to equity ratio adalah bagian dari rasio solvabilitas. Kasmir (2008) menjelaskan bahwa rasio solvabilitas atau leverage ratio merupakan rasio yang digunakan untuk mengukur sejauh mana aktiva perusahaan dibiayaioleh hutang. Debt to equity ratio sendiri merupakan rasio yang digunakan untuk menilai perbandingan hutang dengan ekuitas perusahaan. Rasio ini berguna untuk mengetahui besaran dana yang disediakan oleh kreditor dengan perusahaan. Semakin tinggi nilai DER suatu perusahaan, maka hal tersebut menunjukkan komposisi hutang perusahaan semakin besar jika dibandingkan dengan modal sendiri. Penelitian yang dilakukan oleh Suryaputri (2003) menyatakan bahwa variabel DER memiliki pengaruh signifikan negatif terhadap PER, hasil penelitian 
Nugroho, et al/Jurnal Ekonomi Syariah Teori dan Terapan Vol. 6 No. 11 November 2019: 2224-2235; DETERMINAN PRICE EARNING RATIO SAHAM YANG TERDAFTAR DALAM JAKARTA ISLAMIC INDEX (JII) PERIODE 2011 - 2017

menyimpulkan bahwa investor kehilangan tingkat kepercayaan terhadap perusahaan yang memiliki hutang yang besar.

$\mathrm{H}_{1}=$ debt to equity ratio berpengaruh negatif terhadap price earning ratio.

\section{Return on Equity}

Sudana (2011) ROE menunjukkan kemampuan perusahaan untuk menghasilkan laba setelah pajak dengan menggunakan modal sendiri yang dimiliki oleh perusahaan. ROE merupakan bagian dari rasio profitabilitas yang berfokus pada profitabilitas dari investasi atas ekuitas, hal tersebut juga dapat diartikan bahwa ROE sama saja dengan net income yang diperoleh para pemegang saham atas per rupiah vang yang telah mereka investasikan terhadap perusahaan. Dikutip dari Hayati (2010) :

"Semakin tinggi return on equity akan memberikan kepercayaan yang relatif besar kepada para investor untuk menanamkan investasinya dalam bentuk saham pada perusahaan Real Estate dan Property yang terdaftar dalam Bursa Efek Indonesia. Besarnya modal yang dimiliki perusahaan dapat memacu pertumbuhan perusahaan kearah yang lebih baik jika modal dikelola dengan baik".

$\mathrm{H}_{2}=$ debt to equity ratio berpengaruh positif terhadap price earning ratio.

\section{Dividend Payout Ratio}

Dividend merupakan bagian dari keuntungan yang didapatkan oleh sebuah bisnis yang nantinya akan dibayarkan kepada para pemegang saham. Katy (1996) mengutarakan bahwa perusahaan pada umumnya membayarkan dividend dalam bentuk vang, saham atau bahkan keduanya. Jumlah dari tiap dividend bergantung kepada keadaan perusahaan. Kebijakan dividend dari suatu perusahaan menentukan pendapatan laba perusahaan, yaitu antara membayar dividend dan melakukan investasi kembali dalam perusahaan. Penelitian yang dilakukan oleh Aji (2012) memaparkan bahwa dividend payout ratio memiliki pengaruh positif terhadap perubahan price earning ratio. Apabila laba yang ditahan oleh perusahaan semakin kecil maka pertumbuhan laba yang akan dibagikan oleh perusahaan kepada para investor akan semakin besar sehingga penilaian saham atas price earning ratio akan meningkat.

$\mathrm{H}_{3}=$ dividend payout ratio berpengaruh positif terhadap price earning ratio.

\section{Current Ratio}

Current ratio merupakan bagian dari rasio likuiditas. Menurtu Kasmir (2014) Rasio lancar atau (current ratio) merupakan rasio untuk mengukur kemampuan perusahaan membayar kewajiban jangka pendek atau hutang yang akan jatuh tempo pada saat ditagih secara keseluruhan. Nilai current ratio yang tinggi tidak hanya menggambarkan kemampuan perusahaan dalam melunasi 
Nugroho, et al/Jurnal Ekonomi Syariah Teori dan Terapan Vol. 6 No. 11 November 2019: 2224-2235; DETERMINAN PRICE EARNING RATIO SAHAM YANG TERDAFTAR DALAM JAKARTA ISLAMIC INDEX (JII) PERIODE $2011-2017$

hutang jangka pendek tetapi juga dapat mengindikasikan adanya dana yang menganggur (idle cash) sehingga akan mengurangi tingkat laba atau profitabilitas dari perusahaan. Penelitian yang dilakukan oleh Sigian (2004) menyatakan bahwa current ratio memiliki pengaruh yang negatif terhadap price earning ratio dari suatu perusahaan, sehingga dalam penelitiannya ia menyimpulkan bahwa current ratio dan price earning ratio memiliki hubungan yang negatif.

$\mathrm{H}_{4}=$ current ratio berpengaruh negatif terhadap price earning ratio.

Model analisis dari penelitian adalah sebagai berikut :

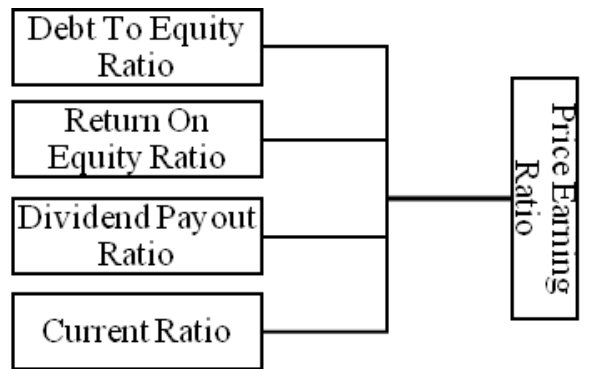

Sumber : data diolah

\section{Gambar 1.}

\section{Model Analisis}

\section{METODE PENELITIAN}

Pendekatan yang digunakan dalam penelitian ini adalah pendekatan kuantitatif, variabel dependen yang digunakan dalam penelitian ini adalah price earning ratio. Anshori (2009) menyatakan bahwa apabila terdapat dua variabel yang saling berhubungan, sedangkan bentuk hubungannya adalah bahwa perubahan variabel yang satu mempengaruhi atau menyebabkan perubahan pada variabel yang lain, maka variabel yang mempengaruhi atau variabel penyebab perubahan tersebut merupakan variabel bebas. variabel bebas (independent) yang digunakan adalah debt to equity ratio, return on equity, dividend payout ratio dan current ratio.

\section{Teknik Analisis}

Penelitian ini akan menggunakan Vector Error Correction Model (VECM). Vector error correction model merupakan salah satu model turunan dari Vector Autoregression (VAR). Asumsi - asumsi yang harus dipenuhi dalam metode analisi data VECM sama seperti VAR, namun pada VECM semua data haruslah stasioner pada tingkat diferensiasi pertama. Model VECM telah diterapkan secara luas dala spesifikasi dinamis mengenai analaisis ekonomi.

Model VECM dipilih karena hasil analisis Teknik dengan menggunakan metode tersebut dapat menjelaskan hubungan antar variabel baik dalam jangka pendek maupun panjang serta menilai apakah hubungan tersebut signifikan atau tidak signifikan. Data akan diolah menggunakan aplikasi Eviews 8. Terdapat beberapa tahapan dalam melakukan analisis dengan metode VECM, berikut adalah tahapan yang akan digunakan untuk menganalisis data menggunakan Teknik VECM : 
Nugroho, et al/Jurnal Ekonomi Syariah Teori dan Terapan Vol. 6 No. 11 November 2019: 2224-2235; DETERMINAN PRICE EARNING RATIO SAHAM YANG TERDAFTAR DALAM JAKARTA ISLAMIC INDEX (JII) PERIODE 2011 - 2017

\section{Uji Stasioner}

Dalam pendekatan penelitian VECM yang menggunakan data time series, pengujian stasioner data sangat diperlukan untuk mendapatkan data pada variable - variable yang hendak diteliti adalah data yang normal dan terdistirbusi dengan baik. Data ekonomi yang bersifat time series umumnya memiliki sifat stokastik, yaitu memiliki trend yang tidak bersifat stasioner. Uji stasioner yang akan dilakukan pada penelitian ini menggunakan uji Augmented Dicky Fuller (ADF) yang akan dilakukan pada derajat yang sama sehingga dapat diperoleh sebuah data yang bersifat stasioner.

$H_{\circ}$ dalam uji stasioner menujukkan adanya unit root dalam data, dan sebaliknya $H_{1}$ menunjukkan tidak adanya unit root dalam data. Jika hasil uji stasioneritas yang sudah dilakukan

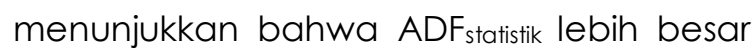
dari nilai Mackinon Critical Value maka $\mathrm{H}_{0}$ ditolak dan $\mathrm{H}_{1}$ diterima, hal tersebut berarti data tidak memiliki root dan sudah staioner. Sedangkan jika nilai ADF $_{\text {statistik lebih }}$ kecil daripada nilai Mackinon Critical Value maka $\mathrm{H}_{0}$ diterima dan $\mathrm{H}_{1}$ ditolak, hal tersebut berarti data memiliki root dan tidak stasioner.

\section{Uji Lag Optimal}

Ketika hasil uji stasioner sudah dilakukan dan didapat temuan bahwa data time series yang digunakan dalam penelitian sudah stasioner, maka analisa dilanjutkan pada tahap berikutnya yaitu Uji Lag Optimum. Harris (1995) menyatakan bahwa jika lag yang digunakan dalam sebuah pengujian stasioner terlalu sedikit, hal tersebut dapat mengakibatkan residual dari regresi tidak akan menampilkan proses white noise sehingga model tidak dapat mengestimasi actual error secara tepat.

Enders (2004) mengemukakan bahwa penentuan lag optimal dalam analisa vector autoregression (VAR) sangat penting dilakukan karena dari variabel endogen (tetap atau dependen) dalam sistem persamaan akan digunakan sebagai variabel eskogen (bebas atau terikat). Terdapat beberapa kriteria untuk melalukan uji lag optimum diantaranya adalah Akaike Information Criterion (AIC), Schwarz Criterion (SC) dan Hanan-Quinn (HQ). kriteria tersebut digunakan untuk mecari lag optimal dengan memilih kriteria mana yang memiliki final prediction error correction (FPE) atau dapat dikatakan bahwa jumlah dari AIC, SC dan $\mathrm{HQ}$ yang paling kecil diantara lag yang diajukan.

\section{Uji Kointegrasi Johansen}

Setelah data mendapatkan lag optimumnya, pengujian dilanjutkan pada tahap berikutnya yaitu Uji Kointegrasi. Shafiyah (2013) menjelaskan bahwa uji kointegrasi memberikan implikasi bahwa dalam sebuah sistem persamaan mengimplikasikan bahwa dalam sistem tersebut terdapat error correction model yang menggambarkan adanya hubungan 
Nugroho, et al/Jurnal Ekonomi Syariah Teori dan Terapan Vol. 6 No. 11 November 2019: 2224-2235; DETERMINAN PRICE EARNING RATIO SAHAM YANG TERDAFTAR DALAM JAKARTA ISLAMIC INDEX (JII) PERIODE 2011 - 2017

yang dinamis dalam jangka pendek secara konsisten dengan hubungan jangka panjangnya. Uji kointegrasi dapat dijalankan dengan menggunakan metode Johansen Cointegration.

Uji kointegrasi dilakukan dengan menggunkan metode Johansen Cointegration dengan menggunakan analisis trace statistic dan statistik uji eigen maksimum dengan tingkat kepercayaan a $=5 \%$ akan memunculkan hipotesis seberti berikut :

$\mathrm{H}_{0}=$ tidak terdapat $r$ persamaan kointegrasi $\mathrm{H}_{1}=$ terdapat $r$ persamaan kointegrasi.

Kriteria uji johansen cointegration akan menerima $\mathrm{H}_{0}$ apabila statistic uji trace dan uji eigen maksimum memiliki nilai lebih kecil dari nilai kritis pada saat $a=5 \%$ atau $p$ value lebih kecil dari nilai signifikansi $a=5 \%$. $\mathrm{H}_{1}$ akan diterima apabila yang terjadi adalah sebaliknya.

\section{Uji Model VECM}

Jika hasil uji kointegrasi mengindikasikan adanya kointegrasi pada data yang diuji, tahap berikutnya dalam metode analisis data dengan metode VECM adalah melakukan estimasi model VECM dari data yang diteliti. Jika data time series dalam model VAR terbukti memiliki kointegrasi maka analisis model VECM diterapkan pada data untuk mengetahui hubungan jangka pendek serta jangka Panjang dari data yang diteliti.Hasil data yang sudah diolah menggunakan model VECM dinyatakan memiliki pengaruh apabila nilai t-statistik data tersebut lebih besar daripada nilai t-tabel yang dimiliknya.

\section{Uji Impulse Response Function}

Impulse response function merupakan analisis yang digunakan untuk menetapkan respon dari suatu variabel bebas terhadap shock (guncangan) dari variabel tertentu. Impulse pada tahap ini menghasilkan sebuah respon bukan sebuah dampak seperti sebuah regresi sederhana, dimana respon merupakan kumpulan dari dampak yang terjadi pada tiap variabel yang terjadi antar waktu.

Ajija dkk., (2011) menyatakan bahwa fungsi dari impulse response function adalah untuk melacak respon saat ini dan masa depan setiap variabel akibat shock suatu variabel. Dalam penelitian ini IRF digunakan untuk mengetahui dan melihat respon efek guncangan variabel PER terhadap variabel DER, ROE, DPR dan CR.

\section{Forecast Variance Decompose}

Variance error decomposition pada model VECM serupa dengan model VAR yang merupakan bagian dari model tersebut. Wijaya (2012) berpendapat bahwa forecast error decomposition memisahkan variasi dari jumlah variabel yang diestimasi menjadi komponen komponen shock dengan asumsi variabel variable shock tidak saling berkorelasi. Forecast error decomposition juga akan memberikan informasi mengenai bagian 
Nugroho, et al/Jurnal Ekonomi Syariah Teori dan Terapan Vol. 6 No. 11 November 2019: 2224-2235; DETERMINAN PRICE EARNING RATIO SAHAM YANG TERDAFTAR DALAM JAKARTA ISLAMIC INDEX (JII) PERIODE $2011-2017$

pergerakan shock dari sebuah variabel terhadap shock variabel lainnya pada periode sekarang dan periode yang akan datang.

\section{HASIL DAN PEMBAHASAN}

\section{Hasil Uji Stasioner}

Sebuah data dinyatakan stasioner apa bila nilai ADF lebih besar dari nilai critical value data tersebut. Melalui hasil uji stasioner dapat dilihat bahwa data pada tingkat level hanya data variabel PER saja yang stasioner sedangkan data variabel DER, ROE, DPR dan CR belum stasioner pada tangkat uji stasioner level. Sedangkan pada uji tingkat $1^{\text {st }}$ different variabel Price Earning Ratio (PER), Debt to Equity Ratio (DER), Return on Equity (ROE), Dividend Payout Ratio (DPR) dan Current Ratio (CR) memiliki nilai ADF yang lebih besar jika dibandingkan dengan critical value pada tingkat signifikansi 1\%, $5 \%$ dan 10\%. Hasil tersebut menunjukkan bahwa variabel Price Earning Ratio (PER), Debt to Equity Ratio (DER), Return on Equity (ROE), Dividend Payout Ratio (DPR) dan Current Ratio (CR) stasioner pada tingkat first different.

\section{Hasil Uji Lag Optimum}

Nilai Akaike Information Creition (44.00662) lebih kecil jika dibandingkan dengan nilai Schwars Creition (45.80181), melalui perbandingan tersebut maka Akaike Information Creition dipilih menjadi indikator penentu lag optimum. Hasil uji lag optimum menunjukkan bahwa rekomendasi lag optimum adalah sebesar 5 berdasarkan tanda bintang terbanyak.

\section{Hasil Uji Kointegrasi Johansen}

Berdasarkan data yang diperoleh dari uji trace test, nilai uji trace test lebih besar jika dibandingkan dengan critical value. hal yang sama juga dapat dilihat dalam uji maximum eigen value dimana hasil uji tersebut memiliki nilai yang lebih tinggi jika dibandingkan dengan nilai critical value, hasil tersebut menunjukkan bahwa variabel debt to equity ratio, return on equity, dividend payout ratio dan current ratio memiliki kointegrasi pada lag 0.

\section{Hasil VECM}

Tabel 1.

Hasil Uji VECM

\begin{tabular}{|c|c|c|c|}
\hline \multicolumn{4}{|c|}{ Jangka Panjang } \\
\hline $\begin{array}{l}\text { Variabel } \\
\text { Eksogen }\end{array}$ & Koefisien & $\begin{array}{c}t- \\
\text { statistic }\end{array}$ & Keterangan \\
\hline DER & $\begin{array}{c}- \\
19.39707\end{array}$ & 30.9937 & Signifikan \\
\hline ROE & $\begin{array}{c}- \\
0.060379\end{array}$ & $\begin{array}{c}- \\
0.17458 \\
\end{array}$ & Signifikan \\
\hline DPR & 0.328657 & 0.63083 & Signifikan \\
\hline$C R$ & $\begin{array}{c}- \\
0.081880\end{array}$ & 1.21189 & Signifikan \\
\hline \multicolumn{4}{|c|}{ Jangka Pendek } \\
\hline $\begin{array}{l}\text { Variabel } \\
\text { Eksogen }\end{array}$ & Koefisien & $\begin{array}{c}t- \\
\text { statistic }\end{array}$ & Keterangan \\
\hline CointEql & $8.23 \mathrm{E}-06$ & 0.00088 & Signifikan \\
\hline $\mathrm{D}(\operatorname{DER}(-1))$ & 0.207665 & 0.78501 & Signifikan \\
\hline $\mathrm{D}(\operatorname{DER}(-2))$ & 0.095415 & 0.36156 & Signifikan \\
\hline $\mathrm{D}(\operatorname{DER}(-3))$ & 0.083687 & 0.30152 & Signifikan \\
\hline $\mathrm{D}(\operatorname{DER}(-4))$ & $\begin{array}{c}- \\
0.006456 \\
\end{array}$ & $\begin{array}{c}- \\
0.02378\end{array}$ & Signifikan \\
\hline $\mathrm{D}(\operatorname{ROE}(-1))$ & 0.131092 & 1.10819 & Signifikan \\
\hline$D(R O E(-2))$ & $\begin{array}{c}- \\
0.089590 \\
\end{array}$ & $\begin{array}{c}- \\
0.78304 \\
\end{array}$ & Signifikan \\
\hline$D(\operatorname{ROE}(-3))$ & $\begin{array}{c}- \\
0.072611 \\
\end{array}$ & $\begin{array}{c}- \\
0.64156 \\
\end{array}$ & Signifikan \\
\hline
\end{tabular}


Nugroho, et al/Jurnal Ekonomi Syariah Teori dan Terapan Vol. 6 No. 11 November 2019: 2224-2235; DETERMINAN PRICE EARNING RATIO SAHAM YANG TERDAFTAR DALAM JAKARTA ISLAMIC INDEX (JII) PERIODE $2011-2017$

\begin{tabular}{|c|c|c|c|}
\hline$D(\operatorname{ROE}(-4))$ & $\begin{array}{c}- \\
0.094939\end{array}$ & $\begin{array}{c}- \\
0.81519\end{array}$ & Signifikan \\
\hline $\mathrm{D}(\mathrm{DPR}(-1))$ & 0.202539 & 1.78241 & Signifikan \\
\hline $\mathrm{D}(\mathrm{DPR}(-2))$ & 0.360943 & 2.61405 & Signifikan \\
\hline D (DPR (-3)) & 0.129192 & 0.83969 & Signifikan \\
\hline $\mathrm{D}(\mathrm{DPR}(-4))$ & 0.181820 & 1.37597 & Signifikan \\
\hline $\mathrm{D}(\mathrm{CR}(-1))$ & 0.031913 & 1.15405 & Signifikan \\
\hline $\mathrm{D}(\mathrm{CR}(-2))$ & $\begin{array}{c}- \\
0.041076 \\
\end{array}$ & $\begin{array}{c}- \\
1.51524 \\
\end{array}$ & Signifikan \\
\hline $\mathrm{D}(\mathrm{CR}(-3))$ & $\begin{array}{c}- \\
0.003568\end{array}$ & $\begin{array}{c}- \\
0.13290\end{array}$ & Signifikan \\
\hline$D(C R(-4))$ & $\begin{array}{c}- \\
0.015814\end{array}$ & $\begin{array}{c}- \\
0.59269\end{array}$ & Signifikan \\
\hline
\end{tabular}

Keterangan : t-tabel $=1.99656$ pada taraf signifikan $5 \%$

niali t-tabel diperoleh dari $d f=n-k$

Sumber : Eviews 9, data diolah

\section{Dapat dilihat bahwa koefisien}

CointEql bernilai negatif, hal tersebut menunjukkan bahwa terdapat penyesuaian dari jangka pendek menuju jangka panjang dengan koreksi kesalahan sebesar 8.23E-06. Hasil uji VECM menjelaskan bahwa terdapat penyesuaian dari pengaruh jangka pendek menuju jangka panjang memerlukan koreksi eror sebesar 8.23E-06. Melalui hasil uji model VECM dapat dilihat bahwa variabel DER, ROE DPR dan CR memiliki pengaruh negatif signifikan terhadap PER dalam jangka panjang. Sedangkan dalam jangka pendek variabel DER dan DPR memiliki pengaruh positif signifikan terhadap PER dan variabel $\mathrm{ROE}$ dan $\mathrm{CR}$ memiliki pengaruh negatif signifikan terhadap PER.

\section{Impulse Response Function}

Uji Impulse Response Function dilakukan untuk melihat respon variabel pada masa sekarang maupun masa yang akan datang yang diakibatkan oleh guncangan atau shock dari variabel tertentu. Jangka periode yang digunakan untuk menjelaskan hasil uji IRF dalam penelitian ini adalah 30 periode. Guncangan pada variabel DER,ROE,DPR dan CR pada periode ke-1 belum direspon oleh variabel PER. DER mulai mencapai keseimbangan pada periode 15 hingga periode 30 yang berarti guncangan pada variabel DER setelah periode 15 tidak lagi disarankan. Guncangan variabel ROE mencapai keseimbangan pada periode 20 hingga periode 30. Guncangan variabel DPR mencapai keseimbangan pada periode 20 hingga periode 30 dan guncangan pada variabel CR mencapai keseimbangan pada periode 25 hingga periode 30 .

\section{Forecast Variance Decompose}

Sumber terbesar yang menjelaskan pergerakan price earning ratio adalah dividend payout ratio yang menjelaskan pergerakan sebesar $24,21 \%$ diikuti oleh return on equity yang menjelaskan pergerakan price earning ratio sebesar $1,49 \%$. Current ratio menjelaskan pergerakan variabel current ratio sebesar $0.65 \%$ dan debt to equity ratio menjelaskan pergerakan price earning ratio sebesar $0.25 \%$.

\section{SIMPULAN}

Pengaruh Debt to Equity Ratio Terhadap Price Earning Ratio.

Hasil penelitian menunjukkan bahwa debt to equity ratio berpengaruh signifikan terhadap price earning ratio baik 
Nugroho, et al/Jurnal Ekonomi Syariah Teori dan Terapan Vol. 6 No. 11 November 2019: 2224-2235; DETERMINAN PRICE EARNING RATIO SAHAM YANG TERDAFTAR DALAM JAKARTA ISLAMIC INDEX (JII) PERIODE $2011-2017$

dalam jangka panjang. Kesalahan pada perilaku sebelumnya diperbaiki sebesar $0.29 \%$. Koefisien debt to equity ratio bernilai -19.39707, nilai tersebut menunjukkan debt to equity ratio memiliki hubungan negatif terhadap price earning ratio.

Hasil tersebut sesuai dengan hipotesis awal dimana debt to equity ratio memiliki hubungan negatif terhadap PER. Hasil penelitian sama seperti penelitian yang dilakukan oleh Suryaputri (2003) yang berkesimpulan bahwa debt to equity ratio berpengaruh negatif terhadap price earning ratio. Darminto (2013) dalam tulisannya menjelaskan bahwa berdasarkan teori signal debt to equity ratio memili pengaruh negatif dimana semakin tinggi nilai debt to equity ratio maka akan semakin rendah harga sahamnya. Hal tersebut terjadi karena tingkat kepercayaan pasar terhadap saham menurun dikarenakan tingkat hutang saham yang makin tinggi yang nantinya akan mengakibatkan nilai price earning ratio semakin menurun.

Pengaruh Return on Equity Ratio Terhadap Price Earning Ratio.

Hasil penelitian menunjukkan bahwa return on equity memiliki hubungan yang signifikan dalam jangka panjang terhadap price earning ratio. Kesalahan pada periode sebelumnya diperbaiki sebesar $1,5 \%$ atau dalam kata lain mencapai titik keseimbangan pada periode ke 20. Nilai koefisien return on equity sebesar -0.060379 hal tersebut menunjukkan bahwa return on equity memiliki pengaruh negatif terhadap price earning ratio.

Hasil penelitian tersebut bertentangan dengan hipotesis awal dimana return on equity memiliki pengaruh positif terhadap price earning ratio, namun hasil penelitian sama dengan penelitian yang pernah dilakukan oleh Erlin (2014) dimana hasil penelitian yang dilakukan meyatakan bahwa return on equity memiliki pengaruh negative terhadap price earning ratio. Investor masih belum dapat mempercayai kemampuan perusahaan dalam mengelola modal meskipun nilai return on equity cenderung mengalami peningkatan. Jika dilihat dari susunan rumusnya return on equity dan price earning ratio memiliki keasamaan dimana peningkatan laba bersih setelah pajak akan meningkatkan nilai return on equity sedangkan peningkatan laba setelah pajak akan meningkatkan laba perlembar saham. Kenaikan dalam laba bersih setelah pajak akan meningkatkan nilai earning pershare, peningkatan pada earning pershare akan mengakibatkan penurunan nilai price earning ratio.

Pengaruh Dividend Payout Ratio Terhadap Price Earning Ratio.

Hasil penelitian menunjukkan bahwa dividend payout ratio memiliki hubungan yang signifikan dalam jangka 
Nugroho, et al/Jurnal Ekonomi Syariah Teori dan Terapan Vol. 6 No. 11 November 2019: 2224-2235; DETERMINAN PRICE EARNING RATIO SAHAM YANG TERDAFTAR DALAM JAKARTA ISLAMIC INDEX (JII) PERIODE $2011-2017$

panjang terhadap price earning ratio. Kesalahan dalam periode sebelumnya diperbaiki sebesar $24 \%$ atau dalam kata lain mencapai titik keseimbangan pada periode ke 20. Nilai koefisiennya sebesar 0.328657 hal tersebut menunjukkan bahwa dividend payout ratio memiliki hubungan negatif terhadap price earning ratio.

Hasil penelitian bertentangan dengan hipotesis awal dimana dividend payout ratio seharusnya memiliki hubungan positif terhadap price earning ratio. Namun hasil penelitian yang dilakukan sama dengan penelitian yang dilakukan oleh Sushil (2009) dimana secara keseluruhan nilai dari koefisien dividend payout ratio memiliki hubungan negatif terhadap price earning ratio selama lima tahun selama total periode data tujuh tahun. Hasil penelitian ini dapat didukung dengan teori tax preference. Sudana (2011) menyatakan bahwa dalam teori tersebut dividend payout ratio memiliki peran negatif terhadap harga pasar saham perusahaan dimana semakin tinggi dividend yang dibagikan perusahaan maka semakin rendah harga pasar saham yang bersangkutan.

Pengaruh Current Ratio Terhadap Price

\section{Earning Ratio}

Hasil penelitian menunjukkan bahwa current ratio berpengaruh signifikan terhadap price earning ratio dalam jangka panjang. Kesalahan pada perilaku sebelumnya diperbaiki sebesar $0.65 \%$ atau dalam kata lain mencapai titik keseimbangan pada periode ke 20. Koefisiennya bernilai -0.081880 , nilai tersebut menunjukkan current ratio memiliki hubungan negatif terhadap price earning ratio.

Hasil penelitian sama seperti hipotesis awal yaitu current ratio memiliki hubungan negatif terhadap price earning ratio. Hasil penelitian sama seperti penelitian yang dilakukan oleh Sigian (2004) dimana ia menyatakan bahwa current ratioi memiliki pengaruh negatif terhadap price earning ratio. Nilai current ratio yang tinggi tidak selamanya mengirimkan sinyal yang baik terhadap investor mengenai kesanggupan perusahaan dalam memenuhi kebutuhan jangka pendeknya.

Tingginya tingkat current ratio juga dapat diartikan sebagai makin banyaknya idle cash yang dimiliki perusahaan. Idle cash atau dana yang menganggur dapat megurangi tingkat produktifitas perusahaan akibat dari penurunan laba adalah menurunnya price earning ratio perusahaan, karena harga saham mencerminkan kapitalisasi laba dari sebuah saham.

\section{DAFTAR PUSTAKA}

Abdul, Halim. 2015. Auditing (Dasar-dasar Audit Laporan Keuangan). Jilid 1. Edisi Kelima. UPP STIM YKPN: Yogyakarta. 
Nugroho, et al/Jurnal Ekonomi Syariah Teori dan Terapan Vol. 6 No. 11 November 2019: 2224-2235; DETERMINAN PRICE EARNING RATIO SAHAM YANG TERDAFTAR DALAM JAKARTA ISLAMIC INDEX (JII) PERIODE $2011-2017$

Aji, Meygawan Nurseto dan Irene Rini Demi Pangestuti. 2012. Analisi Faktor Faktor Yang Mempengaruhi PriceEarning Ratio (Studi Empiris Pada Perusahaan Manufaktur yang Terdaftar di Bursa Efek Indonesia 2007-2010). Diponegoro Journal of Management. 1(1). 382391 .http://ejournal-

sl.undip.ac.id/index.php/diom

Ajija, Shocrul Rohmatul, et all. 2011. Cara Cerdas Menguasai Eviews. Jakarta: Salemba Empat.

Anshori, Muslich dan Sri Iswati. 2009. Metodologi Penelitian Kuantitatif. Surabaya: Universitas Airlangga

Darminto, Rizky Augustine Perdana dan Nengah Sudjana. 2013. Pengaruh Return on Equity (ROE), Earning per Share (EPS) dan Debt to Equity Ratio (DER) terhadap Harga Saham. Jurnal Administrasi Bisnis (JAB). 2 (1).

Enders, Walter. 2004. Applied Econometric Time Series. Edisi 2. University of Alabama

Fahmi, Irham. 2014. Manajemen Keuangan Perusahaan dan Pasar Modal. Jakarta : Mitra Wacana Media

Harris, R. 1995. Cointegration Analysis in Econometric Modelling. New York: Prentince Hall

Hayati, Nurul. 2010. Faktor Yang Mempengaruhi PER Sebagai Salah Satu Kriteria Keputusan Investasi Saham pada Perusahaan Real
Estate dan Property di BEl. Jurnal Managemen dan Akuntansi, 11(1). 53-62

Huda, Nurul. 2007. Investasi pada Pasar Modal Syariah. Jakarta : Kencana

Kasmir. 2008. Analisis Laporan Kevangan. Jakarta : PT Raja Grafindo Persada.

Kasmir.2014. Analisa Laporan Kevangan. Depok : Rajawali Pers

Katy Buys, Jonathan Berohn. 1996. Investment Basic for Women : The Essential Guide To Taking Charge of Your Money. New York : Theresa Murtha

Kumar, Suhil and Warne, D P. 2009. Parametric Determinants of PriceEarning Ratio in Indian Capital Market. IUP Journal of Applied Finance. 15(9). 63-82

Metwally,M. 1995. Teori dan Model Ekonomi Islam. Jakarta: PT. Bangkit Daya Insana

Sartono, Agus. 2001. Manajemen Kevangan Teori dan Aplikasi. Edisi 4. Yogyakarta : BPFE

Shafiyah, Mas'udi Faridatush. 2013. Pengaruh Instrumen Moneter Syariah terhadap Pembiayaan Investasi di PT. Bank Muamalat Indonesia, Tbk. Skripsi Institut Pertanian Bogor.

Sigian, Radot R. 2004. Analisis Faktor Faktor yang Mempengaruhi Price Earning Ratio Pada Perusahaan Manufaktur di BEJ. Tesis Tidak 
Nugroho, et al/Jurnal Ekonomi Syariah Teori dan Terapan Vol. 6 No. 11 November 2019: 2224-2235; DETERMINAN PRICE EARNING RATIO SAHAM YANG TERDAFTAR DALAM JAKARTA ISLAMIC INDEX (JII) PERIODE 2011 - 2017

Dipublikasikan.

Manajemen, Magister Universitas

Diponegoro.

Sudana, I Made. 2011. Manajemen Keuangan Perusahaan : Teori \& Praktik. Jakarta : Erlangga

Suryaputri, V. Rossje dan Cristina Dwi A. 2003. Pengaruh Faktor Leverage, Dividen Payout, Size, and Country Risk terhadap Price Earning Ratio.
Media Riset Akuntansi, Auditing, dan Informasi. 1

Tandelilin, Eduardus. 2010. Portofolio dan Investasi : Teori dan Aplikasi. Yogyakarta: Kanisius

Wijaya, Prakuta. 2015. Dampak Guncangan (Shock) Internal dan Eksternal Terhadap Stabilitas Sistem Kevangan Di Indonesia. Skripsi Universitas Airlangga 